\title{
TRADISI PEMBERIAN PITI BALANJO PADA PEREMPUAN DALAM MASA PINANGAN DI NAGARI MANGGILANG
}

\author{
Salma, Kharisma Aliya, Masna Yunita \\ Universitas Islam Negeri Imam Bonjol Padang \\ salma@uinib.ac.id,kharismabm1722@gmail.com, \\ masnayunita@uinib.ac.id
}

\section{ABSTRAK}

Tulisan ini bertujuan untuk mengungkapkan tradisi unik masyarakat Nagari Manggilang di Kabupaten Lima Puluh Kota. Secara adat, laki-laki yang melamar seorang perempuan memberikan piti balanjo setiap minggu kepada perempuan yang dilamarnya selama dalam masa pertunangan. sementara hal itu tidak diatur dalam Islam. Piti balanjo itu adalah sejumlah uang yang diberikan oleh laki-laki pada tunangannya dan tidak bagian dari mahar. Data dikumpulkan melalui wawancara dengan pasangan bertunangan maupun pasangan menikah yang sebelumnya memberikan piti balanjo, keluarga inti, ninik mamak kepala suku dan ulama lokal. Data dianalisis secara deskriptif dengan cara reduksi, display dan verifikasi. Hasil penelitian menunjukkan bahwa tradisi maagiah pitih balanjo sudah berlangsung turun-temurun. Makna pemberian piti balanjo adalah bukti tanggung jawab dan pengikat laki-laki. Piti balanjo ini diberikan kepada perempuan melalui wali. Alasan masyarakat mempertahankan tradisi ini adalah untuk memberitahukan bahwa seorang perempuan telah dilamar oleh seorang laki-laki guna menghindarkan orang lain melamarnya. Oleh karena itu, piti balanjo ini termasuk hibah, karena ia diberikan atas dasar kerelaan hati untuk memuliakan perempuan.

Kata Kunci: Adat, Khitbah, Perkawinan, Perempuan. 


\section{ABSTRACT}

This article aims to explore the unique traditions of the people of Nagari Manggilang in Lima Puluh Kota regency. A Man who proposes a woman gives piti balanjo (some money) every week to the woman during the engagement period, although that is not regulated in Islam. The piti balanjo is amount of money given a man to his fiance and it is not part of the dowry. Data was gathered through depth interview with engaged and married couples who had previously given piti balanjo, a nuclear family, ninik mamak, leader of tribes and local ulama. Data were analyzed descriptively by reduction, display and verification. The results showed that the tradition of maagiah pitih balanjo has been going on for generations. The meaning of giving piti balanjo was a proof of responsibility and binding for the man. The piti balanjo was given to woman through her guardians. The reasons of the people to maintain this tradition was to notify that a woman has been proposed by a man and also to prevent others proposing her. Therefore, the piti balanjo was included as a bequest, because it was given on the basis of willingness to glorify woman.

Keywords: Custom, Married, Proposal (Khitbah), Woman.

\section{A. Pendahuluan}

Peminangan merupakan langkah pendahuluan menuju ke arah perjodohan antara seorang pria dengan seorang wanita. Islam mensyariatkannya, agar masingmasing calon mempelai dapat saling mengenal lebih dekat dan memahami pribadi mereka masing-masing. Ketika seorang laki-laki telah mantap dalam memilih perempuan yang ingin dinikahinya baik melalui sifat-sifatnya maupun kehidupannya secara keseluruhan, maka ia menyampaikan lamaran (khitbah) kepada perempuan tersebut. Dalam hukum Islam peminangan telah diatur dengan cukup 
jelas. Peminangan ini termasuk pendahuluan pernikahan atau pendahuluan akad. Secara etimologi, khitbah berarti bicara dan bisa juga diartikan sebagai ucapan berupa nasihat, ceramah, pujian dan lain sebagainya (Sabiq, 1983). Al-Zuhaili (1997) mengatakan bahwa khitbah adalah cara masing-masing pihak baik laki-laki maupun perempuan untuk saling mengenal di antara keduanya, karena khitbah itu menjadi jalan untuk mengenal masing-masing karakter dan kepribadian. Berdasarkan pengertian itu, maka setelah khitbah, peristiwa ini berlanjut pada konsep ta'aruf (saling mengenal) setelah terjadi perkenalan pertama pada khitbah.

Salah satu faktor yang dapat memantapkan hati dan meneguhkan pendirian adalah ketika masing-masing mengenal dan memandang yang lain pada saat melamar, sehingga mereka bisa menilai kedirian calon pasangannya baik dari segi kecantikan/ketampanannya untuk menyegerakan perkawinan atau sebaliknya mereka bisa melihat sesuatu keburukan yang bisa meneguhkan hatinya untuk mengatakan tidak. Zahrah( 1957) menyebutkan, meskipun dibenarkan untuk mengenal satu sama lain tetapi tetap dalam koridor yang dihalalkan seperti kebolehan melihat perempuan yang dilamar pada batas wajah dan telapak tangan sebelum maupun ketika melamar dan tidak dibenarkan untuk berdua-duaan/bersunyi-sunyi atau berduan di tempat yang sepi / khalwat.

Pada satu sisi, kecantikan dan keburukan fisik orang yang dilamar bisa diketahui melalui pandangan mata langsung maupun melalui perantara. Adapun untuk mengetahui secara mendalam tentang karakter masingmasing dapat diketahui dalam proses pengenalan lanjutan atau ta'aruf. Umumnya dalam syariat Islam diketahui bahwa untuk mengenal karakter tidak disarankan secara langsung tetapi melalui perwakilan atau utusan. Sabiq (1983) menjelaskan bahwa Rasulullah s.a.w pernah 
mengutus Ummu Sulaim untuk mengenali seorang perempuan dengan memerintahkan untuk melihat otot tumit/betis dan menghidu tengkuknya. Dalam riwayat lain dengan cara menghidu bau mulutnya. Dalam hal ini, hanya orang jujur dan amanah yang dapat dipercayai untuk melakukan tugas-tugas ta'aruf ini.

Secara adat, meminang atau melamar artinya meminta seorang wanita untuk dijadikan istri. Peminangan adalah kegiatan/usaha ke arah terjadinya hubungan perjodohan antara seorang laki-laki dengan seorang perempuan. Nagari Manggilang, Kabupaten Lima Puluh Kota, Provinsi Sumatera Barat juga dikenal adanya tradisi dalam peminangan. Kebiasaan tersebut dikenal masyarakat dengan istilah maagiah piti balanjo. Artinya, selama masa pertunangan calon suami diharuskan memberi sejumlah uang kepada calon istrinya setiap minggu sampai berakhir masa pertunangannya. Uang itu menjadi milik pribadi tunangannya dan dia berhak menggunakan uang itu sesuka hatinya. Piti balanjo ini tidak termasuk mahar ataupun pemberian lainnya sebelum perkawinan.

Syari'at menetapkan aturan-aturan tertentu dan umum dalam peminangan. Di sisi lain menetapkan halhal yang dilarang seperti larangan melamar perempuan dalam masa iddah dan ada juga larangan meminang pinangan orang lain (Daud, 2002: 175). Salam (2016: 8496) mengemukakan bahwa hadis tentang khitbah yang diriwayatkan oleh Imam Abu Daud yang berasal dari jalur Ahmad bin Amr bin Sarh dengan redaksi la yakhtubu 'ala khitbati akhihi berkisar pada tataran yuridis dan etika. Dalam tataran yuridis, hadis tersebut menunjukkan larangan terjadinya peminangan terhadap pinangan orang lain, sedangkan dalam tataran etika atau tasawuf, hadis tersebut lebih mengacu pada terciptanya kehidupan yang harmonis. Biasanya, dalam komunitas muslim tertentu, 
orang yang mengajukan pinangan adalah pihak lakilaki, baik laki-laki itu sendiri yang datang kepada pihak perempuan untuk menyampaikan pinangannya atau mengutus anggota keluarganya yang perempuan untuk melakukannya, sedangkan pihak perempuan berada dalam status orang yang menerima pinangan. Oleh karena itu, tata cara peminangan dalam kelompok masyarakat Muslim berbeda sesuai dengan tradisi peminangan yang berlaku di daerah tersebut.

Di Pekalongan seperti yang ditemukan Maknun, (2013) ada beberapa tahapan sebelum pelaksanaan perkawinan. Di antaranya adalah tradisi nakonke yaitu kedatangan pihak keluarga laki-laki pada keluarga perempuan untuk menanyakan dan memastikan statusnya sebagai seorang perempuan yang belum dilamar oleh orang lain. Masyarakat Osing Banyuwangi memiliki tradisi unik dalam peminangan. Dalam kajian Wagianto (2017) ditemukan bahwa di wilayah ini dikenal tradisi meminang dengan cara kawin colong. Kawin colong adalah perbuatan seorang laki-laki yang mencuri atau melarikan seorang perempuan untuk dijadikan istrinya tanpa sepengetahuan orang tua pihak perempuan. Kawin colong pada masyarakat Osing merupakan warisan leluhur atau budaya secara turun temurun, sehingga masyarakat berasumsi bahwa adanya kawin colong bukanlah sebuah persoalan yang negatif. Sa'dan (2017) menemukan bahwa masyarakat Kuta Baro Aceh Besar mengembalikan pemberian mahar dua kali lipat apabila pembatalan khitbah itu dilakukan oleh pihak calon mempelai perempuan. Pembatalan khitbah oleh calon mempelai perempuan dengan membayar pemberian dua kali lipat di masyarakat Kuta Baro Aceh Besar merupakan hukuman ta'zir, karena pembatalan itu termasuk pada bentuk ingkar janji. Pengembalian uang/materi yang diberikan pada masa pertunangan juga ditemukan pada 
masyarakat Bugis Makasar seperti yang dikemukakan oleh Elvira (2014) dan Abbas (2018: 203-2018). Berbeda halnya pada masyarakat Bima, sebagaimana dikemukakan oleh Wardatun (2016: 311-366), dalam tradisi masyarakat ini, pihak perempuan memberikan ampa co'i ndai (uang belanja termasuk mahar) pada laki-laki dalam masa pertunangan khusus bagi calon suami dengan status PNS.

Tidak hanya di wilayah-wilayah Indonesia, tradisi unik meminang juga dikenal dalam masyarakat Muslim Melayu Malaysia. Salleh (2015) mengemukakan tentang adat pertunangan dilangsungkan bersama adat merisik dan meminang. Dalam keadaan tertentu, adat merisik ditiadakan. Ini kerana adat merisik merupakan perjumpaan secara tertutup wakil pihak lelaki dengan perempuan yang ingin dipinang sebagai tanda pertanyaan resmi pihak laki-laki. Fungsi ritual dalam adat-istiadat pertunangan masyarakat Melayu Malaysia di antaranya bertujuan untuk memperkenalkan kedua pihak lelaki dan perempuan sebelum ikatan perkawinan.

Riset tentang tradisi pemberian uang kepada calon istri setelah terjadinya peminangan ini berlokasi di Nagari Manggilang Kabupaten Lima Puluh Kota Sumatera Barat. Data yang digunakan terdiri dari data primer dan sekunder. Pengumpulan data dilakukan dengan cara observasi, wawancara mendalam dan studi dokumentasi. Peneliti telah melakukan observasi pertunangan dan pemberian piti balanjo beberapa kesempatan, pada bulan Juni, Juli dan Agustus 2018. Peneliti juga telah memperoleh data yang memadai melalui wawancara mendalam dengan orang-orang yang dipandang penting untuk memberikan informasi tentang tradisi maagiah piti balanjo ini yaitu beberapa pasangan bertunangan/pernah bertunangan, beberapa anggota keluarga inti, beberapa mamak kepala suku dan ulama lokal. Data yang diperoleh baik melalui 
observasi, wawancara dan dokumentasi diolah dan dideskripsikan menurut analisis data Miles (1992: 16-19) yaitu reduksi data, display dan verifikasi.

\section{B. Pembahasan}

\section{Khitbah dalam Konteks Fikih}

Khitbah merupakan penyampaian kehendak untuk menikah. Kata khitbah secara sederhana diartikan dengan penyampaian kehendak untuk melangsungkan ikatan perkawinan. Kata ini telah menjadi bahasa Arab standar yang terpakai dalam pergaulan sehari-hari (Syarifuddin, 2014). Khitbah ini disyariatkan dalam al-Qur`an di antaranya dalam surat al-Baqarah (2): 235 dan dalam banyak hadis Rasulullah s.a.w.

Fikih mengatur beberapa hal tentang peminangan. Pertama, perempuan yang boleh dipinang adalah mereka yang tidak sedang terikat dalam perkawinan dan tidak sedang dilamar oleh laki-laki lain (Rusyd, 1986). Syariat melarang seorang laki-laki melamar perempuan dalam empat kriteria lainnya, pertama, perempuan dalam ikatan perkawinan meskipun telah ditinggal lama oleh suaminya. Kedua, perempuan dalam masa iddah wafat. Ketiga, perempuan dalam masa iddah talak raj'iy. Keempat, perempuan dalam masa iddah talak bain.

Khitbah tetap saja mendatangkan akibat hukum tersendiri terhadap kedua pihak. Hubungan keduanya tetap dianggap asing (ajnabi), sehingga peminangan itu tidak memunculkan hak dan kewajiban. Sabiq (1983) menjelaskan bahwa pada dasarnya khitbah hanyalah janji untuk menikah dan tidak akad itu sendiri dan perjanjian itu tidak mengikat kedua pihak. Masing-masing pihak berhak untuk membatalkan pinangan itu dengan cara yang baik, meskipun pembatalan lamaran itu dipandang kurang 
terpuji. Syarifuddin (2014) menjelaskan bahwa peminangan tidak diatur dalam Undang-undang Nomor 1 Tahun 1974 tentang Perkawinan tetapi diatur dalam Kompilasi Hukum Islam pasal 1, 11, 12 dan 13. Seluruh pasal ini mengadopsi konsep peminangan dalam mazhab utamanya Syafi'iyah.

\section{Tradisi Peminangan di Nagari Manggilang}

Nagari Manggilang adalah salah satu nagari yang ada di wilayah administrative Kabupaten Lima Puluh Kota Provinsi Sumatera Barat. Batas wilayah Nagari Manggilang di sebelah barat adalah Nagari Pangkalan Koto Baru, sebelah timur berbatasan dengan Nagari Batu Sasak, sebelah utara berbatasan dengan Nagari Pangkalan Koto Baru, dan sebelah selatan berbatasan dengan Nagari Koto Alam. Nagari Manggilang terdiri dari empat jorong yaitu, Jorong Lubuk Jantan, Jorong Subarang Pasar, Jorong Mudiak Pasar dan Jorong Pasar Manggilang. Jumlah penduduk Nagari Manggilang secara keseluruhan sebanyak 6.000 jiwa (Kabupaten 50 Kota Dalam Angka, 2017). Nagari Manggilang memiliki luas wilayah 15.815 ha dan sebagian besar dipergunakan untuk bangunan, fasilitas umum dan lahan pertanian serta perkebunan. Secara administratif pemerintahan Nagari Manggilang dipimpin oleh seorang wali nagari terpilih periode 2016-2021 yaitu Ridwan dan pada setiap jorong yang ada dikepalai oleh wali jorong yang merupakan perpanjangan tangan dari wali nagari. Jorong Lubuk Jantan dikepalai oleh Sudirman, Jorong Subarang Pasar dikepalai oleh M.Kholis, Jorong Mudiak Pasar dikepalai oleh Budi Mulia Hariyanto dan Jorong Pasar Manggilang dikepalai oleh Yultriman.

Mata pencaharian penduduk di Nagari Manggilang beranekaragam. Ada yang bekerja sebagai petani, pedagang, buruh, dan pegawai negeri sipil. Petani merupakan pekerjaan utama penduduk di daerah ini. Pertanian adalah 
salah satu sumber alam terbesar yang dimanfaatkan penduduk Nagari Manggilang untuk mempertahankan hidup dan mengembangkan perekonomian. Tanaman yang ditanam penduduk Manggilang biasanya berupa padi, ubi kayu, pohon pinang, pisang, jengkol dan petai. Sedangkan untuk daerah perbukitan biasanya mereka menanam pohon gambir dan durian. Di Nagari Manggilang terdapat 7 suku, masing-masing suku dipimpin oleh beberapa orang angku datuak. Secara khusus para angku datuak (penghulu) memiliki beban moril dalam perkembangan sikap dan kepribadian anak kamanakan yang satu suku dengan mereka. Adapun suku di Nagari Manggilang adalah Suku Malayu Tangah, Suku Malayu Tigo Niniak, Suku Piliang, Suku Piliang Baruah, Suku Pitopang, Suku Caniago, dan Suku Domo. Setiap suku dipimpin oleh beberapa angku datuak. Suku Malayu Tangah dipimpin oleh Khaidir Dt. Bijo Dirajo, Bahar Dt. Ulak Sumaro, Irsal Dt.Sati dan Sarial Dt.Paduko Tuan. Suku Malayu Nan Tigo dipimpin oleh Mansur Am Dt. Rajo Nan Kuniang, Sarial Dt. Angkat Dirajo dan Uyun Dt. Rajo Imbang. Suku Pilaing dipimpin oleh M.Hatta Dt. Mangkuto Rajo dan Budi Dt. Rajo Mangkuto. Suku Piliang Buruah dipimpin oleh Nazarudin Dt. Sindo. Suku Pitopang dipimpin oleh Basir Dt. Rajo Panghulu dan Yuliardi Dt. Tan Rajo Lelo. Suku Caniago dipimpin oleh Armencan Dt. Parpatiah, M.Nur Dt. Rajo Indo, dan Dedi Dt. Bindo Lelo. Suku Domo dipimpin oleh Ali Munir Dt. Paduko Rajo dan M.Yunus Dt. Rajo Basa.

Salah satu tugas angku datuak adalah mendampingi anak kemenakannya ketika proses pernikahan. Dalam melaksanakan upacara adat perkawinan sebagaimana halnya yang dimiliki oleh suku Minangkabau umumnya yaitu menempatkan perkawinan menjadi persoalan dan urusan kaum kerabat, mulai dari mencari pasangan, membuat persetujuan, pertunangan dan perkawinan, 
bahkan sampai kepada segala urusan akibat perkawinan itu. Masyarakat umumnya berpandangan bahwa saat peralihan yang sangat penting dan harus dilalui oleh setiap orang sebagai penganut agama Islam adalah upacara perkawinan yaitu peralihan dari masa remaja menuju kehidupan berkeluarga. Setiap orang tua menginginkan perkawinan anaknya dilaksanakan sesuai dengan ketentuan syariat dan prosedur adat yang berlaku. Perkawinan tersebut mendapat restu dari kedua orang tua, sanak famili dan dibenarkan oleh masyarakat (PPKD, 1997).

Ada beberapa tahapan dalam tradisi masyarakat Nagari Manggilang ketika melamar seorang perempuan sampai pada hari perkawinan. Pertama, datang ulokulok dengan makna datang bertanya. Datang ulok-ulok merupakan upacara pertama yang dilakukan oleh perwakilan pihak laki-laki ke rumah pihak perempuan dengan tujuan untuk bertanya kepada pihak perempuan. Biasanya orang yang dianjurkan datang dari pihak laki-laki adalah keluarganya yang perempuan saja dan diutamakan orang yang lebih tua. Acara ini dipimpin oleh mamak rumah (ninik mamak sebagai kepala suku). Acara dimulai dengan membicarakan calon menantu secara resmi. Pertanyaan yang diajukan oleh orang tua laki-laki biasanya menanyakan status anak perempuan yang akan dilamar. Hal ini dilakukan untuk menghindari agar mereka tidak melamar seorang perempuan yang sudah dilamar oleh orang lain. Jika mereka sudah mendapatkan kepastian tentang status kesendirian anak perempuan itu, maka seminggu setelah ulok-ulok, pihak laki-laki akan datang kembali untuk memasuki pelaksanaan pememinangan tahap berikutnya.

Kedua, maanta tando dengan makna pelaksanaan prosesi peminangan (khitbah). Ketika maanta tando pihak laki-laki membawa benda yang dikenal dengan istilah tando 
berupa cincin sabantuak dan kain sapatogak. Cincin sabantuak artinya pemberian yang berbentuk satu buah cincin dengan nilai 1 atau 2 mas dan mungkin lebih bagi golongan tertentu. 1 mas dalam takaran masyarakat Minangkabau termasuk masyarakat Nagari Manggilang biasanya seberat 2.5 gram. Adapun makna tando kain sapatogak adalah seperangkat pakaian yang disiapkan pihak laki-laki untuk perempuan yang dilamarnya. Kain sapatogak di Nagari Manggilang terdiri dari sepasang sepatu, bahan kain untuk membuat baju kurung, jilbab, selendang, sapu tangan dan ada juga yang menyertakan satu buah handuk. Tando yang diberikan itu gunanya adalah untuk membuktikan keseriusan lakilaki melamar perempuan pilihannya tersebut. Pada saat maanta tando ini, maka dibuat perjanjian antara pihak lakilaki dan pihak perempuan. Perjanjian itu berisi tentang hal-hal yang harus dilakukan dalam masa pertunangan. Perjanjian masa pertunangan itu biasanya berlangsung minimal selama satu bulan dan maksimal selama 6 bulan. Selama masa pertunangan ini, ditentukan dan disepakati juga jumlah piti balanjo yang akan diberikan oleh pihak lakilaki pada perempuan. Jumlah piti balanjo yang disepakati sesuai dengan kemampuan laki-laki yang melamar dan biasanya berkisar antara 100.000 rupiah sampai 500.000 rupiah setiap minggu.

Ketiga, tombe dengan makna balasan kedatangan pihak laki-laki. Setelah berakhirnya masa pertunangan, dengan segala syarat-syarat yang harus dipenuhi di dalamnya dan hampir mendekati hari pernikahan, maka selanjutnya pihak perempuan dan keluarganya datang ke rumah pihak laki-laki membawa perlengkapan (rantang) yang berisi makanan. Biasanya satu buah rantang berisi hidangan makanan lengkap seperti nasi, lauk dalam bentuk gorengan, lauk dalam bentuk gulai (berkuah) baik gulai daging maupun ayam dan rebusan sayur. Setelah rantang itu diberikan pada keluarga laki-laki, 
selanjutnya pihak laki-laki datang ke rumah perempuan membawa tombe atau balasan dari rantang yang dibawa oleh perempuan. Biasanya tombe itu berupa isi kamar pengantin yang disediakan oleh laki-laki untuk keperluan kamar pengantin di rumah perempuan yang dipinang. Di Kota Payakumbuh dan di Kabupaten Lima Puluh Kota, tradisi ini dikenal dengan nama maisi sasuduk (melengkapi isi kamar pengantin) mulai dari tempat tidur, lemari baju, kasur, bantal, alas kasur, (bed cover), kelambu dan selimut. Kualitas semua bahan sasuduk sesuai dengan kemampuan ekonomi calon mempelai laki-laki.

Keempat, manatak ari yaitu menentukan hari pertunangan, akad perkawinan serta menetapkan hari pelaksanaan pesta perkawinan. Nama lain kegiatan ini adalah bapokat yang dihadiri oleh keluarga inti dan kerabat suku. Setelah berakhirnya masa pertunangan sesuai dengan kesepakatan keluarga laki-laki dan keluarga perempuan, maka setelah itu kedua keluarga akan membicarakan waktu pernikahan. Peranan orang tua dan ninik mamak suku sangat penting dalam situasi dan kondisi ini, kebanyakan masyarakat Manggilang mengambil hari Kamis atau Jum'at untuk melaksanakan akad nikah. Ini didasarkan keyakinan bahwa hari Kamis atau Jum'at adalah di antara hari yang istimewa dalam Islam dan hari baik bulan baik dalam sebutan masyarakat Manggilang.

Kelima, mamanggia niniak mamak yaitu memanggil/ mengajak ninik mamak kepala suku untuk merundingkan pertunangan dan persiapan perkawinan. Setelah menetapkan hari pernikahan dalam manatak ari, maka keluarga akan memanggil ninik mamak kepala suku dari kedua calon pasangan suami istri. Tujuan memanggil ninik mamak adalah untuk memberitahukan kepada mereka jika kemenakannya akan melangsungkan pernikahan setelah berakhirnya pertunangan selama tiga beberapa 
bulan. Ketika memanggil ninik mamak kepala suku diadakan acara makan basamo (makan bersama) sebagai bentuk rasa syukur kepada Allah s.w.t. Setelah itu, ninik mamak kepala suku memberitahukan kepada kemenakannya yang lain kalau salah satu kemenakannya akan melangsungkan pernikahan.

Keenam, pelaksanaan akad nikah. Akad nikah merupakan tahap akhir pelamaran dan wujud dari perjanjian yang telah disepakati oleh kedua belah pihak ketika pihak perempuan menerima lamaran seorang lakilaki. Akad nikah yang dilakukan sesuai dengan ketentuan yang diajarkan dalam syariat Islam. Perempuan diwakili oleh walinya yaitu ayah atau walinya yang lain apabila tidak ada ayah dan beberapa orang saksi. Dalam proses akad nikah ini disebutkan kalau kedua calon pasangan mempelai telah bertunangan selama sekian bulan. Pada saat akad ini juga diberitahukan kepada khalayak bahwa pihak laki-laki telah menunaikan pemberian piti balanjo selama dalam masa pertunangan itu.

Ketujuh, baralek yaitu pelaksanaan pesta perkawinan (walimat al-urs). Baralek atau pesta perkawinan adalah upacara yang dilakukan untuk memeriahkan akad perkawinan dan merupakan hari yang berkesan dan penting bagi kedua mempelai. Oleh karena itu, dibutuhkan biaya yang cukup banyak utamanya untuk biaya resepsi dan makanan. Selain itu, di antara aspek yang menjadi patokan adalah penetapan harinya yaitu hari baik bulan baik seperti yang dikemukakan sebelumnya. Maksudnya hari yang baik untuk melaksanakan akad dan pesta perkawinan. Biasanya setiap daerah mempunyai hari baiknya masing-masing untuk melangsungkan acara ini. Di Manggilang acara baralek ini biasanya dilakukan pada hari Sabtu dan Minggu. 


\section{Pemberian Piti Balanjo}

Di Nagari Manggilang, Kabupaten Lima Puluh Kota Provinsi Sumatera Barat ada sebuah tradisi sebelum pernikahan yaitu keharusan seorang laki-laki yang telah diterima lamarannya untuk memberikan sejumlah uang kepada perempuan yang dilamarnya selama dalam masa pertunangan. Yuliardi Datuak Tan Rajo Lelo dari suku Pitopang mengatakan bahwa tradisi pemberian dalam masa pertunangan ini disebut dengan maagiah pitih balanjo. Sejarah awal tradisi maagiah pitih balanjo ini tidak diketahui masyarakat secara pasti, karena sudah sangat lama tradisi ini menjadi bagian dalam tata cara peminangan menuju perkawinan di Nagari Manggilang. Meskipun tidak ada aturan tertulis yang menjelaskan pelaksanaan tradisi ini, masyarakat masih tetap mempertahankanya. Menurut Muhammad Hatta Datuak Mangkuto Marajo, pemberian pitih balanjo ini sudah ada sejak zaman nenek moyang sehingga hal ini menjadi sebuah tradisi yang sampai sekarang masih tetap dipertahankan oleh penduduk Nagari Manggilang. Menurutnya, ada keharusan pihak laki-laki, memberikan sejumlah uang mulai dari Rp. 50.000 rupiah sampai Rp. 500.000 dan bahkan lebih kepada perempuan yang telah menerima lamarannya. Piti balanjo ini diberikan setiap minggu. Di antara tokoh adat mengatakan, meskipun keduanya belum ada ikatan yang sah, namun uang itu adalah sebagai tanda keseriusan dari laki-laki untuk menikahi perempuan yang dipinangnya, sehingga laki-laki lain tidak berhak (tidak boleh) untuk melamar perempuan itu. Piti balanjo itu tidak dapat digantikan dengan barang atau benda lain meskipun barang atau benda itu senilai dengan piti balanjo yang diberikan.

Demikian juga menurut Syafril wakil Datuak Parpatiah, piti balanjo yang diberikan selama masa pertunangan merupakan suatu tradisi yang sudah lama 
dan dijaga hingga masa kini. Setiap laki-laki yang akan menikah pasti memberikan piti balanjo kepada tunangannya dan besarannya sesuai dengan kesepakatan kedua belah pihak. Tradisi ini ibaratnya adat nan indak lakang dek paneh indak lapuak dek hujan. Artinya adat atau tradisi yang sudah berlangsung lama dan masih dilaksanakan sampai sekarang. Meskipun tradisi ini tidak ditemukan secara tertulis. Piti balanjo itu sifatnya mengikat, namun sampai sekarang tidak ada sanksi khusus yang diberikan kepada orang yang tidak mengikuti tradisi ini. Hanya saja apabila ada pasangan yang tidak memberi uang belanja maka pernikahannya menjadi buah bibir (pergunjingan) di masyarakat. Kebiasaan masyarakat ketika ada orang yang menikah, maka masyarakat di sekitarnya menanyakan tentang jumlah piti balanjo yang telah diterima.

Sebagai satu tradisi yang diketahui, dipatuhi dan dilaksanakan masyarakat, maka terdapat aturan bagi yang melanggar. Meskipun pelanggaran perjanjian adat tentang piti balanjo itu jarang terjadi di nagari ini. Jika ada para pihak yang melanggar janji pertunangan dan pihak lakilaki telah memberikan piti balanjo, maka hukuman adat bagi mereka bergantung pada siapa yang mengingkari kesepakatan (janji). Jika pihak yang melanggar itu adalah pihak perempuan, maka ia wajib mangganti tando dan piti balanjo yang diberikan pihak laki-laki sebanyak 2 kali lipat. Sementara jika yang mengingkari perjanjian adalah pihak laki-laki, maka piti balanjo itu dianggap hilang dan pihak perempuan tidak harus mengembalikannya.

Pemberian piti balanjo dalam rangkaian adat perkawinan di nagari Manggilang merupakan jenis adaik nan taradaiak. Artinya adat ini adalah warisan turuntemurun dari nenek moyang sejak dahulu. Karena tradisi piti balanjo khususnya dan adat Minangkabau umumnya sudah ada sebelum agama Islam masuk ke 
wilayah Minangkabau. Agama Islam yang masuk ke wilayah Minangkabau tidak merusak tatanan adat yang sudah ada, tetapi antara adat dengan agama Islam saling menyesuaikan diri dengan corak kultural masyarakat setempat. Oleh karena itu, pelaksanaan tradisi maagiah piti balanjo sudah menjadi bagian penting dalam tata cara pernikahan di Nagari Manggilang. Makna sebenarnya dari pemberian piti balanjo ini adalah sebagai bukti keseriusan seorang laki-laki, karena pemberian ini tidak dilihat dari segi nominal yang diberikan, tetapi dari segi kerelaan seorang laki-laki memberikan pada perempuan yang dilamarnya.Tradisi ini juga bermakna sebagai tanda ikatan awal antara calon pasangan suami dan istri. Ketika calon suami telah memberikan piti balanjo kepada calon istrinya, maka secara tidak langsung laki-laki lain tidak berhak (tidak boleh) melamar perempuan itu. Tradisi pemberian piti balanjo ini tidak pernah dilupakan ketika terjadi suatu pernikahan. Ninik mamak kepala suku selaku tokoh adat dan pengampu masyarakat dalam persoalan adat memiliki pemahaman yang sama untuk tetap mempertahankan dan melestarikan tradisi ini, karena tradisi ini menjadi ciri khas adat perkawinan di Nagari Manggilang. Hal ini sesuai dengan ungkapan adat bahwa tradisi ini adalah adat salingka nagari. Artinya, tradisi piti balanjo ini ada di Nagari Manggilang dan belum tentu ada di nagari di wilayah Minangkabau. setiap nagari mempunyai adat masingmasing dan adat yang hidup itu berbeda cara dan makna sesuai dengan pemahaman masyarakatnya.

\section{Alasan dan Cara Pemberian Piti Balanjo}

Berdasarkan informasi yang diterima dari 5 pasangan menikah, beberapa orang pemuda dan beberapa orang ninik mamak kepala suku di Manggilang, diketahui bahwa mereka menjalani masa pertunangan yang cukup lama 
dan laki-laki memberikan piti balanjo pada tunangannya pada masa pertunangan. Kelima pasangan menjalani masa bertunangan minimal 5 bulan. Pihak laki-laki memberikan piti balanjo minimal sebanyak Rp. 100.00- Rp. 500.000 kepada tunangannya setiap minggu. Pihak laki-laki datang setiap minggu ke rumah tunangannya untuk memberikan piti balanjo dan biasanya, kedatangan mereka selalu didampingi oleh ayah, ibu, atau kerabat dekat lainnya. Menurut adat Nagari Manggilang, seorang laki-laki yang telah bertunangan tidak boleh sendirian mengunjungi rumah tunangannya (sekalipun untuk mengantarkan piti balanjo) atau membawa keluar tunangannya tanpa didampingi oleh orang yang dipercaya dari keluarganya. Kadang-kadang ada di antara mereka yang menitipkan piti balanjo itu pada saudara laki-laki tunangannya untuk kemudian diserahkan kepada adiknya. Penyerahan uang belanja ini rutin dilakukan pihak laki-laki setiap minggu selama masa pertunangan. Pihak laki-laki mengatakan bahwa mereka tidak keberatan untuk memberikan piti balanjo kepada tunangannya, karena hal itu sudah menjadi kebiasaan setelah seorang laki-laki telah selesai meminang calon calon istrinya. Mereka menjelaskan bahwa mereka merasa malu jika tidak memberikan piti balanjo pada perempuan yang telah dilamarnya, sehingga pemberian piti balanjo itu sudah termasuk kewajiban yang harus dipenuhinya. Tunangannya menjadikan piti balanjo untuk membeli keperluan dirinya sendiri dan untuk melengkapi kebutuhan pernikahan nantinya. Meskipun demikian, piti balanjo ini di luar mahar dan isi pemberian sasuduk.

Dalam hal pemberian piti balanjo, maka kedua orang tua atau kerabat lainnya tidak ikut campur mengenai jumlah piti balanjo yang diberikan. Yuliardi Dt.Tan Rajo Lelo menjelaskan bahw laki-laki yang sudah meminang seorang perempuan di Nagari Manggilang memiliki 
tanggungan (tanggung jawab) yaitu memberikan piti balanjo kepada perempuan yang akan menjadi istrinya. Pemberian piti balanjo ini dimulai setelah keluarga laki-laki datang ke rumah keluarga perempuan untuk melamar dan keluarga perempuan menerima lamaran itu. Pemberian piti balanjo tidak boleh dilakukan secara langsung antara lakilaki yang meminang dan perempuan yang dipinangnya. Pada pemberian piti balanjo itu harus ada didampingi oleh kerabat dekat. Mereka memahami bahwa sebagai seorang Muslim di Minangkabau, seorang laki-laki dan seorang perempuan tidak boleh berdua-duaan tanpa ada orang lain yang menyertai mereka.

Pihak laki-laki sebagai orang yang bertanggung jawab atas pemberian piti balanjo pada tunangannya tidak merasa diberatkan dengan adanya tradisi ini. Umumnya mereka setuju dan mengikuti tradisi ini dengan kerelaan dan keikhlasan hati. Pelaksanaan tradisi ini bisa menunjukkan sisi keseriusan seorang laki-laki untuk membangun rumah tangga bersama perempuan yang disukainya. Tujuan tradisi ini agar seorang laki-laki tidak menganggap pernikahan tersebut sebagai sebuah permainan, melainkan wadah dan sarana untuk mempertanggungjawabkan anak gadis orang lain di dunia sampai ke akhirat nantinya. Di sisi lain, ada yang mengatakan bahwa dengan adanya pemberian ini, pihak perempuan bisa belajar mengenali dan memahami kemampuan ekonomi laki-laki yang melamarnya. Pada akhirnya, dalam tradisi piti balanjo ini dapat dilihat bahwa seorang laki-laki siap bertanggung jawab dalam pernikahannya, mengetahui hak dan kewajibannya dan dapat mempertahankan hubungan pernikahanitu nantinya. Jika ada masalah dalam rumah tangga, mereka tidak mudah goyah dan tidak mudah pula untuk menjatuhkan talak terhadap istrinya. Selain itu, tradisi piti balanjo ini memberi akibat positif positif bagi pihak laki-laki. Ia bisa 
dihargai oleh masyarakat, karena menurut kebiasaannya ketika terjadi peminangan, maka jumlah piti balanjo yang diberikan pihak laki-laki akan menjadi pembicaraan di tengah masyarakat. Di sisi lain, pemberian piti balanjo pada perempuan dapat memunculkan penghargaan yang tinggi dari keluarga perempuan terhadap keluarga laki-laki yang meminang anaknya.

\section{Kedudukan Pemberian Piti Balanjo dalam Hukum Islam Dan Kajian Gender}

Bakhri sebagai salah seorang ulama di Nagari Manggilang mengatakan bahwa tradisi piti balanjo selama masa pertunangan itu termasuk pada adat yang diadatkan. Dilihat dari pelaksanaannya, pemberian piti balanjo ini bergantung kesepakatan kedua belah pihak yaitu antara keluarga laki-laki dan perempuan. Sejauh pengetahuan beliau, tradisi itu tidak pernah ditinggalkan dalam tata cara pernikahan. Menurutnya, pemberian piti balanjo ini tidak memberatkan dan tidak menjadi beban bagi lakilaki, sehingga pemberian ini dibolehkan menurut syariat Islam. Artinya, jika ada pihak laki-laki yang memilih untuk tidak memberikan piti balanjo pada perempuan yang dipinangnya juga dibolehkan karena hal ini tidak diatur dalam agama Islam. Apalagi di antara keduanya belum ada hubungan yang sah dan pilihan tersebut diterima oleh keluarga perempuan. Dengan sendirinya, maka ia bebas dari kewajiban adat tersebut. Akan tetapi, selama ini dia mengetahui jika pemberian piti balanjo ini selalu dilaksanakan di kampungnya, karena masyarakat akan mempergunjingkan keluarga laki-laki yang tidak memberikan piti balanjo pada tunangannya.

Muhammad Zikri, ulama lain di Manggilang memandang tradisi piti balanjo secara lebih luas. Menurutnya, jenis dan tatacara pertunangan seperti di 
Nagari Manggilang sebenarnya juga tidak dikenal dalam Islam tetapi secara konseptual dalam hukum Islam dikenal ungkapan khitbah. Dari satu sisi, ada kemungkinan khitbah dalam hukum Islam ini secara penamaan sama dengan peminangan di Manggilang tetapi baik tata cara maupun tradisi yang mengiringinya nampaknya cukup berbeda. Oleh karena itu, dari sudut peminangan sebagai upaya seorang laki-laki untuk menikahi seorang perempuan adalah sama. Menurutnya, pertunangan adalah istilah yang biasa digunakan masyarakat setelah terjadinya lamaran. Selama masa itu antara laki-laki dan perempuan belum mempunyai hubungan yang sah ataupun tanggung jawab satu sama lain. Berbeda halnya dengan tradisi di Manggilang, pemberian piti balanjo merupakan suatu bentuk perjanjian antara kedua keluarga. Hukumnya boleh dan tradisi itu dapat dikategorikan hadiah dan juga sebagai bentuk penghargaan yang tinggi bagi perempuan.

Pada dasarnya dalam hukum Islam pemberian seperti tradisi piti balanjo itu tidak dikenal, karena belum ada hak seorang laki-laki untuk memberikan sejenis uang belanja yang terlihat seperti pemberian nafkah kepada perempuan yang dilamarnya. Sementara mereka belum terikat dalam akad pernikahan yang sah. Oleh karena itu, pemberian ini termasuk pemberian yang tidak terikat. Meskipun demikian, jika pemberian piti balanjo ini diwajibkan oleh pihak perempuan maka pemberian ini dilarang dalam hukum Islam. Dalam hal ini, jika seorang laki-laki memberikan piti balanjo dengan ikhlas dan tanpa mengharapkan satu imbalan, maka pemberian ini tidak menyalahi hukum Islam.

Berdasarkan uraian yang telah dikemukakan di atas dapat dipahami bahwa tradisi piti balanjo yang diberikan pihak laki-laki kepada pihak perempuan selama masa pertunangan di Nagari Manggilang digolongkan kepada 
hibah atau pemberian sukarela. Hukumnya adalah boleh, apabila diberikan secara sukarela dan tidak ada unsur memaksa dan terpaksa dari kedua belah pihak. Namun sebaliknya apabila salah satu pihak merasa dirugikan dan terpaksa maka pemberian ini tidak dibenarkan dalam hukum Islam. Uang belanja yang telah diberikan oleh pihak laki-laki tidak boleh ditarik kembali, karena pemberian itu adalah hibah, dan hibah haram hukumnya ketika diminta kembali. Dengan demikian ketika terjadi pembatalan peminangan, maka laki-laki tidak berhak untuk meminta ganti piti balanjo yang telah diberikannya.

Menurut peneliti, dalam hukum Islam ada beberapa jenis pemberian pada pernikahan yang harus ditunaikan oleh seorang laki-laki pada perempuan. Dalam hal ini, suami berkewajiban memenuhi hak-hak material istrinya. Pertama, mahar yang diberikan sebelum akad pernikahan. Jenis dan jumlahnya sesuai dengan adat yang berlaku di daerah masing-masing. Kedua, nafkah (sandang, papan dan pangan) yang wajib diberikan suami kepada isterinya setelah adanya akad pernikahan dan telah berlangsung hubungan seksual di antara mereka. Ketiga, mut'ah yang diberikan oleh mantan suami kepada mantan isterinya setelah putusnya perkawinan diantara mereka. Berdasarkan penjelasan itu diketahui bahwa pada dasarnya seorang laki-laki belum memiliki kewajiban materil terhadap seorang perempuan yang dipinangnya. Inilah tradisi yang ditemukan di Nagari Manggilang, Kabupaten Lima Puluh Kota, Provinsi Sumatera Barat dimana seorang lakilaki yang melamar seorang perempuan dan lamarannya diterima, maka laki-laki tersebut memiliki kewajiban adat untuk memberikan piti balanjo.

Kewajiban piti balanjo ini dilaksanakan selama masa pertunangan. Kewajiban adat seperti ini tidak diatur dalam syariat perkawinan. Piti balanjo tidak termasuk 
mahar sebagai syarat perkawinan yang diatur dalam tata aturan perundang-undangan, karena mahar diberikan oleh laki-laki ketika berlangsung akad pernikahan. Adapun piti balanjo diberikan setelah lamaran diterima oleh pihak perempuan. Selain itu, piti balanjo ini juga tidak termasuk nafkah, karena nafkah diberikan seorang suami setelah adanya akad pernikahan yang sah. Sedangkan pitih balanjo diberikan pada saat seorang laki-laki dan seorang perempuan belum mempunyai hubungan apapun. Oleh karena itu, piti balanjo ini termasuk ke dalam kategori hibah, karena piti balanjo yang diberikan pihak laki-laki kepada perempuan adalah jenis pemberian atas dasar kerelaan hatinya tanpa mengharapkan imbalan. Sesuai dengan maksud hibah itu sendiri yaitu pemberian harta kepada orang lain tanpa imbalan untuk mendekatkan diri kepada Allah s.w.t. Akibatnya, piti balanjo menjadi harta perempuan dan menjadi hak miliknya. Menurut penjelasan para perempuan di Manggilang, piti balanjo cukup bermanfaat bagi mereka. Pemberian ini sesuai dengan syarat harta yang dihibahkan yaitu sesuatu benda atau jasa yang memberi manfaat dan bernilai tinggi bagi orang lain.

Pitih balanjo dapat dikategorikan sebagai hibah karena pemberian ini dimaksudkan untuk memuliakan perempuan dan diberikan tanpa mengharapkan imbalan dari perempuan tersebut. Hibah adalah pemberian hak milik sewaktu masih hidup tanpa ada ganti. Dalam hukum Islam, dijelaskan bahwa segala sesuatu yang diberikan oleh laki-laki kepada perempuan yang dipinangnya, jika tidak termasuk mahar pernikahan, maka pemberian itu dianggap sebagai hibah. Hadiah sebelum pernikahan, hanya boleh dimiliki oleh perempuan sebagai calon istrinya dan bukan untuk keluarganya. 
Piti balanjo sebagai hibah yang telah diberikan oleh seorang laki-laki kepada perempuan pinangannya, haram hukumnya untuk diminta kembali. Dalam hal ini berlaku pepatah adat Minangkabau suruk pamboli tapijak ijab, suruk panjua duo kali lipek ijab (jika pemberi mengurungkan niatnya sebelum akad, maka uang piti balanjo yang telah diberikannya tidak bisa diminta kembali tetapi jika penerima piti balanjo yang mengurungkan niatnya sebelum akad, maka dia harus mengembalikan uang itu dua kali lipat). Setelah adanya akad antara kedua belah pihak maka barang/materi yang telah diberikan oleh pemberi hibah menjadi hak penerima hibah, meskipun terjadi pembatalan peminangan dari pihak laki-laki. Hal ini sesuai dengan maksud hadis Rasulullah s.a.w yang menyatakan bahwa tidak boleh menarik hibah yang telah diberikan kepada penerima hibah, kecuali hibah ayah kepada anaknya. Oleh karena itu, menarik kembali piti balanjo yang telah diberikan oleh calon suami pada calon istrinya termasuk perbuatan yang dilarang dalam hukum Islam.

Budaya Piti Balanjo di Manggilang mencerminkan relasi gender dalam etnik Minangkabau. Etnik Minangkabau adalah salah satu di antara etnik dunia dengan sistem kekerabatan matrilineal terbesar dunia dimana keturunan dihitung dari garis ibu (Evers, 1975). Ketika membicarakan perempuan Manggilang, maka secara secara langsung berarti membicarakan kedudukan perempuan Minangkabau secara umum karena perempuan Manggilang adalah bagian dari perempuan Minangkabau dengan sistem kekerabatan yang sama. Meskipun berfungsi sebagai orang yang diberi sesuatu sebelum menikah, maka ketika pernikahan telah berlangsung, fungsi matrilinealnya mulai dan terus berlangsng.

Dalam sejarah Minangkabau sebagaimana diungkapkan oleh para peneliti bahwa perempuan 
Minangkabau menempati posisi yang tinggi dalam struktur kemasyarakatan termasuk perempuan di wilayah Manggilang. Sanday (2002) menggambarkan derajat perempuan Minangkabau dalam bukunya Women at the Center: Life in a Modern Matriarchy. Dia mengatakan bahwa perempuan Minangkabau telah mengontrol dan menjadi pemain utama dalam ruang-ruang spiritual, adat, perkawinan, kepemilikan properti, kontrol politik publik dan lain-lain. Dia melihat secara dalam bagaimana cara perempuan Minangkabau terlibat dalam aktivitas seremonial, komitmen dalam membesarkan anak berdasarkan adat, dan dengan peran mereka stabilitas adat bisa terjaga. Perempuan juga sebagai pemangku Bundo Kanduang, dimana perempuan sebagai poros dari makrokosmos Minangkabau. Maternal simbol inilah yang menghubungkan garis keturunan, dimana ibu dan anak terikat dalam sebuah hubungan yang bisa memberikan harta atau tanah melalui garis ibu. Pola kehidupan seharihari dimana perempuan senior mendapatkan otoritas, tidak bisa dibandingkan dengan pengalaman masyarakat dimana laki-1aki berkuasa. Chuzaifah (2002) menyikapi hasil kajian Sanday di atas dengan mengatakan bahwa buku itu adalah hasil kajian luar biasa dalam menggambarkan realitas perempuan Minangkabau.

\section{Dalam konteks keindonesiaan, Ariani}

(2015) mengemukakan bahwa budaya matrilineal di Minangkabau mengandung nilai-nilai filosofis khususnya nilai feminism yaitu bahwa budaya matrilineal memposisikan perempuan menjadi sangat berharga dan menjadikan perempuan memiliki hak-hak penuh di kalangan luar rumah, sehingga para perempuan Minangkabau memiliki kepercayaan diri yang lebih dari pada yang lain. Ketinggian martabat perempuan Minangkabau dan penghormatan masyarakat terhadap mereka tidak hanya bertemu dalam kajian-kajian 
faktual tetapi juga terungkap dalam berbagai karya sastra (novel) seperti dalam novel-novel yang ditulis oleh Hamka (Helda, 2016). Dalam konteks yang lebih modern pasca kajian Sanday lebih dari 15 tahun yang lalu, perkembangan perempuan Minangkabau senantiasa mengalami dinamika. Meskipun demikian, realitas matrilineal Minangkabau masih terasa nyata di tengah masyarakat. Perempuan sebagai Bundo Kanduang tetap memperoleh tempat tersendiri dan dihormati lebih di tengah keluarganya (Zamzami, 2010). Irawaty (2019) mengemukakan bahwa dalam adat Minangkabau Bundo Kanduang berperan sebagai aktor intelektual di dalam menyelesaikan berbagai persoalan. Karakteristik perempuan Minangkabau yang egaliter dan memiliki posisi sentral dalam komunitas diungkapkan Idris (2010) cukup teruji ketika berhadapan dengan politik praktis, tetapi Putri (2017) mengemukakan bahwa jaringan kekerabatan matrilinear menjadi modal sosial utamanya bagi perempuan Minangkabau ketika mereka mengusung dirinya sebagai calon anggota legislatif.

\section{Simpulan}

Masyarakat Nagari Mannggilang memiliki adat unik dalam memberitahukan bahwa seorang perempuan telah dilamar oleh seorang laki-laki. Pemberitahuan itu dilakukan melalui tradisi pemberian piti balanjo selama masa pertunangan. Pemberitahuan dengan cara ini, menjadi cara efektif untuk mencegah laki-laki lain untuk melamar perempuan yang sama. Kedua, masyarakat tetap menjaga dan memelihara syariat Islam dengan tidak membiarkan kedua pasangan yang telah bertunangan untuk berduaduaan. Pertemuan di antara mereka ketika melakukan pemberian piti balanjo selalu didampingi oleh keluarga terdekat baik ayah, ibu, paman, bibi maupun saudaranya yang lain. Ketiga, pemberian piti balanjo menjadi salah 
satu pedoman bagi keluarga perempuan jika mereka akan memperoleh menantu yang bertanggung jawab secara materi terhadap anak/kemenakan perempuan mereka. Keempat, pemberian piti balanjo menjadi pedoman juga bagi perempuan untuk menerima atau meneruskan pertunangan itu ke jenjang perkawinan. Apalagi masa pertunangan itu terbilang cukup lama, sehingga dapat memberikan waktu berpikir yang cukup bagi seorang perempuan untuk menerima keberadaan calon suaminya. 


\section{DAFTAR PUSTAKA}

Abbas, Ilham, dkk., 2018, “Hak Penguasaan Istri terhadap Mahar Sompa Perkawinan Adat Bugis Makassar (Kajian Putusan PA Bulukumba Nomor 25/ Pdt.P/2011/PABlk)," Kanun Jurnal Ilmu Hukum, Vol. 20, No. 2, (Agustus).

Ariani, Iva, 2015, “Nilai Filosofis Budaya Matrilineal Di Minangkabau (Relevansinya bagi Pengembangan Hak-hak Perempuan Di Indonesia)", dalam Jurnal Filsafat, Vol. 25, No. 1, Februari 2015.

Chuzaifah, Yuniyanti, 2002, “Dekonstruksi Makna Kuasa dalam Matriarchy", Studia Islamika, Vol. 9, No. 2.

Daud, Abu, 2002, Sunan Abi Daud, Jilid III, Kairo: Dar alHadis.

Evers, H, 1975, Changing patterns of Minangkabau urban land-ownership, Bijdragen tot de Taal, Land-en Volkenkunde, 131, No. 1, Leiden, 86-110.

Helda, Trisna, "Harga Diri Perempuan Minangkabau dalam Novel di Bawah Lindungan Ka'bah Karya Hamka," Jurnal Penelitian Bahasa dan Sastra Indonesia V2.i1 (52-60).

Idris, Nurwani, 2010, “Perempuan Minangkabau dalam Politik," Humaniora, Volume 22, Nomor 2, Juni.

Irawaty \& Zakiya Darojat, 2019, “Kedudukan dan Peran Perempuan dalam Perspektif Islam dan Adat Minangkabau" dalam Hayula: Indonesian Journal of Multidisciplinary Islamic Studies, Vol.3, No.1, Januari.

Maknun, Moch. Lukluil, 2013 , “Adat Pernikahan di Kota Pekalongan," Jurnal Penelitian, Vol. 10, No. 2, November. 
Miles, Mathew B. dan A. Michael Hubermen, 1992. Analisis Data Kualitatif, Alih bahasa Tjetjep Rohendi Rohidi. Jakarta: UI Press.

Putri, Indah Adi, 2017, “Jaringan Kekerabatan Matrilineal Sebagai Modal Sosial Perempuan Caleg dalam Pemilu 2014", Jurnal Antropologi: Isu-isu Sosial Budaya, Vol. 19 (2), Desember, 167-178.

Rika Elvira, 2014, “Ingkar Janji atas Kesepakatan Uang Belanja (Uang Panai') dalam Perkawinan Suku Bugis Makassar," Skripsi, Universitas Hasanuddin.

Rusyd, Ibn,1986, Bidayat al-Mujtahid, Jilid II, Beirut: Dar al-Fikr.

Sabiq, al-Said,1983, Figh al-Sunnah, Jilid II, Beirut: Dar alFikr.

Sa'dan Saifuddin dan Arif Afandi, 2017, "Pengembalian Mahar Berganda Karena Pembatalan Khitbah dalam Pandangan Islam: Analisis terhadap Persepsi dan Praktek Masyarakat Kuta Baro Aceh Besar," Samarah: Jurnal Hukum Keluarga dan Hukum Islam Volume 1 No. 1. Januari-Juni.

Salam, Nor Salam, 2016 "Rekonstruksi Makna Hadis La Yakhtubu al-Rajulu 'Ala Khitbati Akhihi: Sebuah Telaah Ilmu Hadis," De Jure: Jurnal Hukum dan Syari'ah Vol. 8, No. 2.

Salleh, Norhuda \& Yaacob Harun, 2015, "Fungsi Ritual dalam Adat Pertunangan Masyarakat Melayu," Journal of Education and Social Sciences, Vol. 1, (June).

Sanday, Peggy Reeves, 2002, Women at the Center: Life in a Modern Matriarclry, Ithaca: Cornell University Press.

Syarifuddin, Amir, 2014, Hukum Perkawinan Islam di Indonesia, Jakarta: Kencana. 
Tim Penulis,2017, Kabupaten Lima Puluh Kota Dalam Angka 2017.

Tim Penulis, 1997, Proyek Penelitian dan Pencatatan Kebudayaan Daerah Departemen Pendidikan dan Kebudayaan.

Wardatun, Atun, 2016, “Ampa Co'i Ndai Local Understanding of Kafā'a in Marriage among Eastern Indonesian Muslims," Al-Jāmi'ah: Journal of Islamic Studies, Vol. 54, No. 2.

Wagianto, Ramdan, 2017, “Tradisi Kawin Colong pada Masyarakat Osing Banyuwangi Perspektif Sosiologi Hukum Islam," Al-Ahwal, Vol. 10, No. 1, Juni 2017 $\mathrm{M} / 1438 \mathrm{H}$.

Zahrah, Abu, 1957, al-Ahwal al-Syahshiyyah, Beirut: Dar alFikr.

Zamzami, Lucky, 2010, “Peranan Keluarga Matrilineal Minangkabau terhadap Kesejahteraan Perempuan Lanjut Usia" Jurnal Penelitian dan Pengembangan Kesejahteraan Sosial, Vol. 15, No. 2, 152-165.

al-Zuhaili, Wahbah, 1997, al-Figh al-Islami Waadillatuhu, Jilid VII, Beirut: Dar al-Fikr. 
